University of Nebraska - Lincoln

DigitalCommons@University of Nebraska - Lincoln

ANDRILL Research and Publications

Antarctic Drilling Program

$5-2008$

Sediment cores reveal Antarctica's warmer past

Quirin Schiermeier

Nature Publishing Group

Follow this and additional works at: https://digitalcommons.unl.edu/andrillrespub

Part of the Environmental Indicators and Impact Assessment Commons

Schiermeier, Quirin, "Sediment cores reveal Antarctica's warmer past" (2008). ANDRILL Research and Publications. 50.

https://digitalcommons.unl.edu/andrillrespub/50

This Article is brought to you for free and open access by the Antarctic Drilling Program at DigitalCommons@University of Nebraska - Lincoln. It has been accepted for inclusion in ANDRILL Research and Publications by an authorized administrator of DigitalCommons@University of Nebraska - Lincoln. 


\section{Sediment cores reveal Antarctica's warmer past}

\section{Quirin Schiermeier}

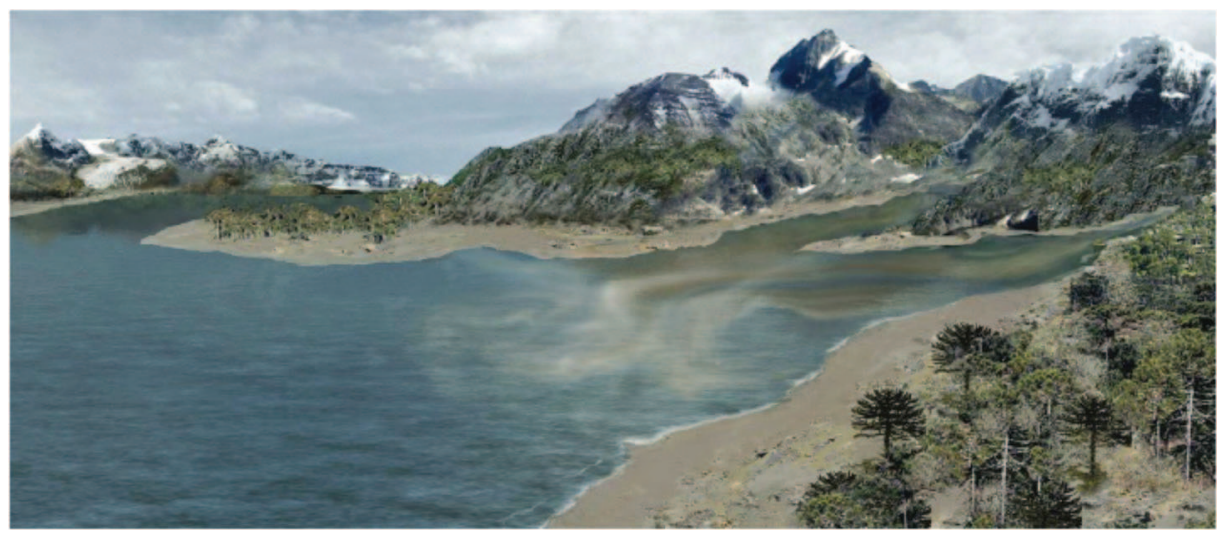

Antarctica's climate may once have been akin to that now seen in southern Patagonia.

A unique drilling project in the western Ross Sea has revealed that Antarctica had a much more eventful climate history than previously assumed. A new sediment core hints that the western part of the now-frozen continent went through prolonged ice-free phases - presumably offering a glimpse of where our warming world might be heading.

Researchers reported initial results from ANDRILL, a US\$30-million international drilling project, on April 16 at the assembly of the European Geosciences Union in Vienna. During the past two years, the team has extracted two cores, each containing some 1,200 meters of sediment, from the seabed below the vast Ross Ice Shelf, a floating extension of the West Antarctic Ice Sheet. Together, the cores provide an almost uninterrupted 17-million-year record of Antarctica's climatic past.

Paleoclimatological records from ice cores, although more detailed and easier to interpret, cover only the past 800,000 years or so. Now, geologists say, Antarctica's history is laid out much more clearly.

"We have every page of the book," says David Harwood, an ANDRILL scientist at the University of Nebraska in Lincoln.

Sediments in the cores, along with microfossils such as pollen and spores, allow researchers to reconstruct sea temperatures and environmental conditions, such as the presence or absence of ice, over millions of years. The analytical work has only just begun, but early results indicate that, during warmer periods, the West Antarctic Ice Sheet and the Ross Ice Shelf shrank rapidly and substantially.

During a warm period some 3.5 million years ago, for instance, the ice sheet may have disappeared completely for around 200,000 years, raising sea levels globally by up to 10 meters.

For the first time, the ANDRILL cores show exactly how ice retreated rapidly and quickly in Antarctica. "That happened at a time when it was three to four degrees warmer than today, owing to atmospheric carbon dioxide concentrations, which we will very likely reach again soon," says Tim Naish, a project leader at the Institute of Geological and Nuclear Sciences in Lower Hutt, New Zealand.

In a poster session at the conference, David Pollard, an ice-sheet modeler at Pennsylvania State University in University Park, presented new simulations confirming that western Antarctica can lose almost all of its ice at temperatures just three to five degrees higher than today's. (During the past 1 million years, Antarctica's ice sheets have expanded.)

The first ANDRILL core covered the paleoclimatic history of the past 7 million years. The second core, drilled between October and December last year, extends the record back to 17 million years ago. It reveals that during a period about 16 million years ago, Antarctica had a climate similar to that found today on the South Island of New Zealand and in southern Patagonia.

"It appears there were rivers, rain and trees in abundance," says Harwood. "That's really the biggest surprise to me so far."

What is still unclear is exactly how, when and where Antarctica's ice sheets started forming during the greenhouse-icehouse climate transition 35 million to 40 million years ago. To find out, the ANDRILL team hopes to resume drilling in 2012 at a new site on the Ross Ice Shelf. 